\title{
Communicating Secular Representation of Partition Violence in About Daddy and Looking Through Glass
}

\author{
Udaya Raj Paudel \\ Doctoral Candidate in English (Communication), Tribhuvan University, Kathmandu, Nepal \\ udayapaudel7@gmail.com
}

Published Date: August 30, 2018

\begin{abstract}
This research study tries to analyze the nature of violence represented in About Daddy (2000 AD) by Meeena Arora Nayak and Looking Through Glass (1995 AD) by MukulKesavan in terms of Priya Kumar's book Limiting Secularism and the locus of the study is based primarily on the critique of partition historiography posited by Gynendra Pandey. Moreover, it tries to explicate what the postcolonial critique of partition historiography reveals the absence of the trauma of the violence and the subaltern perspective of the events. This study keeps into consideration all those critiques as it reads the secular discourse of violence in recent two novels of the partition violence of 1947-About Daddy and Looking Through Glass. By criticizing all kinds of identity markers (nationality, religion, gender...) created through nationalist discourse in history, the paper contends that the representation of Indian partition violence is painted by a secular rather than a communal standpoint in the novels.
\end{abstract}

Keywords: Secular Representation, Partition Violence, Historiography, Subaltern and Religion Conceptual and Contextual Background of The Study

In the analysis of the partition violence, the question of religious coexistence in post partition India and its relation to the concept of secularism is significant. Nehruvian vision of India as a plural and diverse nation is acquired from the western Enlightenment project. When Hindu fundamentalist movement brought Nehruvian concept of secularism in crisis in the decade of 1990s, it became the subject of discussion. The Muslim is considered the enemy of the great Hindu nation. Priya Kumar in the introduction of his book Limiting Secularism states that "we cannot afford to dismiss or trivialize its hegemony, because the anti-Muslim rhetoric of Hindu nationalists has come to consolidate a kind of popular common sense among many Indians" (xiv). He critiques the charge that "all Indian Muslims are, at heart, Pakistanis" (xiv). Thus the position occupied by Muslim is addressed in the present study. The identity of the Indian Muslim is constructed as intimate enemy or the stranger. A Muslim is not quite a friend. To deconstruct the very concept, it requires dealing with Indian partition history in relation to religion, nationalism, violence and the politics of secularism.

Priya Kumar in his book Limiting Secularism quotes the meanings of the word secular given in The Oxford English Dictionary as: "1) concerned with the affairs of this word: not spiritual or sacred, 2) not concerned with religion or religious belief, 3) a. not ecclesiastical or nastic b. not bound by a religious rule, 4) occurring once in an age or century" (5). This kind of separation is not like religio-cultural contexts prevalent in the context of India. It is an exception that secularism is typically understood as the doctrine that is indifferent to religion or can be claimed as otherworldly. Unlike the meanings of The Oxford English Dictionary, Priya Kumar borrows the fairly comprehensive account of secularism as a political doctrine from Donald Smith, one of the earliest commentators on Constitutional secularism in India, who argues that in the liberal democratic tradition secularism is not limited to the principle of separation of religion and state but has to be understood in terms three interrelated components: (I) freedom of religion, which has to do with an individual's relationship to religion so long as it does not impinge upon other basic rights; (2) citizenship, which has to do with the relationship between an individual and the state, whereby the state deals with the individual as citizen rather

www.arjonline.org

Page 1 
than as member of this or that religious persuasion; (3) neutrality which bears upon the relationship between the state and religion and demands that the state not uphold the religious over the secular. (Limiting Secularism 16)

So, secular is first understood in its minimal sense in the socio-eco-politico-cultural context. Priya Kumar writes, "...secularism is the rubric under which most discussions of religious violence and tolerance takes place in India" (xxi). Yes, it is inseparable from social and political nexus (nationalism, citizenship and state). It is expanded from its traditional concern in postcolonial India. Priya Kumar opines "secularism as a cultural and ideological project is constructive of modernity" (2). It is understood as the core of modernity. It has followed the line of Enlightenment, a story of progress and gradual emancipation. Priya Kumar is critical to the term secularism and highlights its politics in relation to the Enlightenment project of the west.

Obviously, the doctrine of secularism was not limited to the question of state but also central to the modernization and liberalization of society itself. Secularism as a cultural and sociological project is at the center. In the context of India, fundamental reconsideration about Indian Muslim is required. Priya Kumar critiquing the ideology of Congress writes "secular nationalism presents Muslims with a very specific and dichotomous choice: either to merge into the nationalist mainstream or to be constructed as communalist and retrogressive" (Limiting Secularism 31). Again, Kumar asserts "I view Partition as a spectral presence that continues to inform and haunt both Hindu-Muslim relations in India and contemporary international relations in the subcontinent" (32). In this way, in the post independence context of India, Indian National Congress has been criticized for the notion of secularism, which overtly prioritizes the individual freedom and covertly perpetuates demonizing the other communities. And the history is continuously shaped on the basis of majority. Jassal and Ben-Ari contend: "Partition and its repercussions continue to shape societal contours and concerns within the context of India, Pakistan and Bangladesh" ("The Partition Motif" 19). Hence, along with the critique of secularism, the critique of Indian partition historiography provides methodological framework in this dissertation.

The analysis of the partition historiography with a whole lot of claims and counterclaims and an enormous body of analysis and writing can never be complete in itself and do justice to the victims of Indian partition. A theoretical critique of Indian history and nationalism then becomes necessary to understand the representation of violence and the construction of different identity markers. Accordingly, while critiquing history, revisionist historiography of the postcolonial bent criticizes the traditional idealist historiography that represents a society in a normalized and homogenized way. In such history, all social texture are smoothed and local specificity are subordinated. And documentary evidence is submerged by paraphrase for the sake of a coherent narratable plot. In the name of nationality and progress, national histories try their best to neglect heterogeneity of a society and the lived experiences of its general public. Historian's history of the partition of India and Pakistan, influenced by colonialist historiography, never falls in an exceptional category that can represent violent events and sufferings in their fullness and from the perspective of the victims.

The nationalist histories of India and Pakistan tend to become variations of master narrative that could be called the history of Europe. Colonial historiography is, no doubt, a 'mimetic' history where we can always see a split in Indian people. And such a split subject of Indians speaks from the narrative that celebrates the nation states. And such narratives are constructed on the basis of the European Enlightenment philosophy constructed through the discourses of both nationalism and imperialism. Even after the independence of India, Indian historiography is filled with a double bind where historians' repudiate the colonizer's construction of Indian people and India and yet follow the colonialist model of history. GyanendraPandey contends: "Although Indian historians have long since moved away from this rather convoluted celebration of the benefits of British rule, they seem nevertheless to have remained tethered to certain fundamental tenets of the colonialist narrative on history, violence and civilization" (Remembering 58). Therefore, official or academic histories of the subcontinent remain mimicry of European historiography that discourages representation of violence, heterogeneity of a society and the painful stories of individuals in the name of rationality, progress and objectivity. 
National histories of both India and Pakistan hide the religiously motivated upheavals of 1947 as irretrievably other in relation to the organs of political rationality and progress. Since no community or individual would like to represent itself as violent and hence uncivilized, official histories shy away from a frank discussion of: "the history of rape, abduction and killing, and the state sponsored drive that followed to evict aliens and recover nationals, especially abducted women and children, irrespective of their wishes, which disturbingly capture the meaning of partition" (Pandey, "Voices" 234). Reasons behind obliterating violence are various. Nevertheless, the professed motive is to secure the peaceful coexistence of different peoples!

Attempts to erase violence from history and by extension memory directly emanates from the centrality of state. In the hierarchy of violence, only the violence perpetrated by state, which is rational and purposeful, is deemed worthy of consideration. JaveedAlam, an Indian Marxist and political scientist, and Suresh Sharma distinguish three kinds of violence. The first kind refers to the violence organized and executed by the state as in Holocaust or in anti-Sikh riots of 1984. The second kind relates to the involvement of large-scale organizations like the one witnessed in India in 1992-1993 where Vishwa Hindu Parishad allegedly incited mass killings over BabariMashjid issue. This violence becomes possible where state becomes a silent witness to those events. The third kind relates to the violence in its raw and unorganized form where people become victims of violence at a moment of loss of sanity and suspension of judgment. This is the violence witnessed at partition and should be forgotten in the best interest of the social harmony and normal everyday life. Any mentioning let alone institutionalization of it is detrimental to the project of nationalism, religion, progress, and rationality. ("Partition" 101)

Detailed representation of violence and its analysis has never been a subject of honest and frank analysis since it is an ongoing and ever present threat in present-day India. People now talk and analyze the Holocaust, for it appears a distant event. Indian historiography makes every attempt to obliterate the violence so as to preserve what is singularly unique about India, its unity in diversity. JaveedAlam argues for a complete obliteration of the legacy of Partition Violence:When we go to people and ask them to remember all that has happened, to recount it for record ... it seems to be morally indefensible since a whole new generation has emerged for whom Partition is a distant historical event. It has gone back into their memory that is important for our politics, for our social lives, for normal interaction between communities. (qtd. in Pandey 60)

It is quite significant to note here that while it is possible to discuss and debate the Holocaust as a distant event, partition violence should be left over to follow its course, out of memory and out of history in the best interest of all. However, this intense harping on unity in diversity seems to collapse when even after fifty years Babari Masjid, Godhara, and many others seem to become a rule rather than an exception. The patronizing move of presenting selective facts of history to its general public is symptomatic of the colonial mentality.Violence is othered by localizing it in space also, "as a characteristic happening in same unassimilated part of the society or the world" (46). Therefore, by localizing violence in time and space, it is always done away with; no effort is made to understand the moment itself.Another strategic way to avoid violence is to cut it short. The high point of the nationalist history according to GyanendraPandey, becomes the companion for the independence from the British rule in 1947. Such history ends in the attainment of Indian independence, as if that is the end point of history. This point of history achieves idealized and glorified representation but the consequently accompanied violence gets a superficial representation as "involving a temporary suspension of reason and normal behavior" ( Pandey, "Prose" 192). Such account "normalizes violence and reduces history to a more or less generalized account of the triumphant march of modernity and progress" ( Pandey, "Prose" 193). It valorizes and idealizes independence of India as a move to achieve ideal state. This model of history depicts violence as a lack of culture, a lumpish chaos, a sudden frenzy and madness of people. Keeping violence in the othered position, historian's history scarily touches the abduction, migration, resettlement, genocidal murders and the tales of rape. Partition violence hence remains unexplored in the textbook histories of India.

American Research Journal of English and Literature

Page 3 
But, independence was partition and as Pandey suggests "partition was violence, a cataclysm, a world torn apart" (Remembering 5). Glorification of independence in the history, therefore, has to be accompanied by a detailed description of massive violence, inhuman cruelty and brutality. As any tale of civilization is equally a tale of barbarism, a balance should be maintained in the representation of independence, partition and violence. During the Partition about half a million people were butchered cold bloodedly simply because they happened to belong to another community. As MushirulHasan observes:an estimated 12.5 million people (as out 3 percent of the independent India) being displaced and uprooted. In the Punjab alone 12 million of Hindus, Muslim and Sikhs were involved in murder, 9 million of people started migration over night and until 1950s, 4000 Muslims a day boarded the train to Pakistan. Many died on the roads, several got lost and perhaps more went mad. Altogether 75,000 women were raped and abducted. Human misery was pervasive; millions were left bereaved, destitute, homeless, hungry and thirsty. Worst of all, millions of the survivor victims were disparately anxious and almost hopeless about their future. There were still many who embarrassed their Hindu, Sikh or Muslim brethrenand wept after 18 months of separation and hellish life of loneliness, anxiety, fear and displacement. ("Human Cost" 50-51)

However, such acts of violence are conveniently repressed in the official histories as if these events were but a freak occurrence. The number of people killed during the Partition has never been established. Patrick French explores the reasons behind the obliteration of violence:It was in the interests of the governments of Attle, Jihhan, and Nehru to play down the scale of the massacres, since they all bore a degree of responsibility for what had happened. Mutual genocide never attracts attention in the way that a one-way genocide does, so the terrible, squalid deaths in countless streets and fields were sidelined. (Liberty or Death 348)

These histories refrain from noticing that independence of India went together with partition of it, which was surrounded, accompanied and constituted by massive violence. Therefore, if national history of India has to become the history of Indian people, "it must represent their tales of suffering and the many sided struggle to liberate India" ( Pandey, "Prose" 204). The history of communalism, sectarianism, strife and bloodshed must be represented in its fullness not as an "inconsequential motif in the larger drama of India's struggle for independence" (206). Valorization of unity of Indians suppresses the painful experiences of subaltern's and marginalized. Hence, GyanendraPandey is right to assert that " history of civilization is at the same time history of violence"(206) and such violence must be articulated in its fullness in the histories, discussed and analyzed so that mankind can think better to eradicate it and march forward towards perfection.

However, GyanendraPandey recognizes certain problems concerning the representation of violence in the history. He contends: The historian seeking to represent violence in the history faces problem of language (how, for example, does one describe pain and suffering) of analytical stance (how can one be objective and describe sufferings at the same time), and of evidence (for does not large scale violence destroy much of its more direct violence?). (Pandey, "Prose" 198)

Actually, there are more the problems of cultural politics, discursive and ideological motives of the language of representation. Education, theology, historiography, philosophy, and science work to produce subjects; legitimizing or authorizing certain versions of the subjects, versions that come to acquire the status of "truths". Through all these moves, partition historiography acquires its status as the representation of truth in the valorization of independence and suppression of violence, trauma and pain of the individuals. Therefore, Partition historiography plays a dangerous politics of othering the violence and suppressing all other perspectives of marginal about partition and portraying itself as the only truthful account of India's struggle for a free nation. And such discourse of history must be doubted and questioned rather than giving it a status of truth.

If history is no more a truthful account of events, is not accessible except in the textual form, can only be apprehended through its effects, is always filled with the play of domination and systems of subjection, and is always written from only one perspective; such history must be radically rewritten. The possibility of multiple 
truths also gives rise to the multiple histories through multiple perspectives. There is indeed a possibility and necessity of writing history from multiple perspectives. Hence the history of partition must be rewritten from the perspectives of subalterns, marginalized, and oppressed; it must be the story of their painful and disconcerting experiences. Moreover, rather than focusing too much on authenticity of representation, partition historiography must focus on the force of representation that is still operative in the present.In the guise of national interests and communal harmony, the history of modern India in line with the history of colonial India, has inflicted much pain and suffering upon its general population. The universalizing gesture of partition historiography obscures the now hidden and now open struggles of millions of people of the subcontinent before, during and after the territorial Independence. Foregrounding its achievement in political front, traditional historians offer a minimalist gesture toward the violence and aim at homogenizing all those tales of murder, rape and abductions in the name of national security and communal harmony. Every attempt is made to erase violence and its historicity. Patrick French states that the liberation of the Indian subcontinent was accompanied by a holocaust of unconscionable horror that bit deeply into the memories of its inhabitants. The psychological legacy of partition has left a much deeper impact on people's mind than the social, economic and political dynamics that led to the division. (Liberty or Death 349)

The nationalist and nativist whose class provenance is usually that of the indigenous elite created in part by colonialism, often end up colluding in the denial of history and the occlusion of heterogeneity. The numerous battles for autonomy or independence of different regional and linguistic minorities, conflict between upper and lower castes and Dalits, Hindu and Muslims, and the aspiration toward more freedom of women and the peasant, have been almost invariably meted out with varying degree of violence by the states. More recently, the union government assertion that the Naxalities pose a single most direct internal threat points to the growing intolerance of the state toward its marginalized population. Hence, the jaded nationalist proposition of unity within disunity and its affirmation of peaceful coexistence simply fails to paint even an approximate picture of the realities and complexities of the country called India.

Despite the hysteric attempts, the facts presented by historian history are sharply contrasted by survivors' accounts of the Partition violence. The scale and force of violence has radically affected the communities and their conception of the past, present, and future. In their daily grappling with the question of violence, communities seem to be torn in between the demands of disciplinary history and their own lived experience. Several methods are applied to come to term with the effects of the violence. One widely used strategy is to maintain silence, to suppress it and try utmost to forget it. GyanendraPandey in his attempt to document the effect of violence states that "individuals would simply refuse to talk about it either because the events are so painful and traumatic that they be best forgotten or simply because the traditional history still holds considerable sway over them" (Remembering 175). Another widely adapted strategy used by individuals and communities is to consign violence as happening out there. Both the victims and perpetrators seem rather reluctant to accept that violence was part of their life: "Nothing happened in our village. All the attacks (against the Muslims) occurred outside" (179). Abductions and rape by other community is either termed as an act of just defense or it is readily consigned to unruly and unsocial elements from outside. More than murder or abductions, rape still remains as a subject of much pain and indignation.

Communities are supposed to construct many and sometimes contradictory accounts of how they prevented rape by sacrificing their own kith and kin with their own hands or by valiantly fighting the enemies. There is a whole body of memoirs mostly in Sikhs community where a father would slaughter his female relatives in the face of imminent assault by the enemy. Or the female fold would willingly jump into the well so as to save their sanctity and dignity. Combined to the attempts at saving the chastity of female is the tale of unflinching determination not to convert into the enemy religion. But events recounting the tales of heroism in the face of adversity are frequently contradicted by women of the same community who tell the desperate struggle of females and even males to save their life by any means: "The inmates were taken to the house of a Sikh 
notable. A female witness gives the account of one forced conversion: Here, a Muslim from a neighbouring village shouted that either we are forcibly converted into Islam or mercilessly butchered. All the Sikhs yielded" (Pandey, Remembering 75).

Again, the willing sacrifice of female fold to save their chastity turns out to be so forceful that they can be said to have been murdered to quench the ego of their male fold. Although there were several events of willing sacrifice in the danger of rape and conversion, the discourse of patriarchal nationalism either overplays or downplays the events in their own interest. Events of death and rape sometimes lose their immediate significance of suffering and fear and assume a lyrical worship of something grand and sacred-Indian tradition, Indian womanhood and Indian valour. Even females seem to have internalized the patriarchal construction of women and womanhood. The report prepared by one Congress activist, Rameshwari Nehru, regarding the events of jumping of women into the well in ThoaKhalsa shows how deep rooted and suffocating are the precepts of chastity for women: the bodies of those beautiful women had become swollen and floated up to the surface of the water. Two or three women still had the bodies of infants clinging to their breasts. There was not a man or woman in our party who did not have tears in his/her eyes ... All of us bowed down to these sati (pure, sacred) women ... We thought of it as our great good fortune that we had been able to visit this site and worship these satis. (Remembering 97)

Regarding rape, the discourse is so created that the immediate suffering of the victim is easily set aside to fulfill something greater motives. Rape is presented as a weapon to exact the revenge on the enemy community in the midst of all out defeats and humiliations. The presumed strategic deployment of rape to humiliate the other and glorify oneself is accorded a sacred place in the popular discourse of communalism and patriarchy. But in a careful analysis it just turns out to be a grand pretext to fulfill one's sexual urges with even more cruelty in the face of mounting violence. Events are numerous where females are made to make sacrifices to fulfill the chauvinistic urges of the males. The attempts at repatriation of women who had gone to the wrong side of the border offer us another good example of suffocating moral precepts. Every woman found herself in a double bind: either to stay with the torturer and kidnapper with heavy heart, or come again to home to face social ostracism. The attempt at repatriation was for a long time carried out without the consent of the affected woman. Some even made attempts to return to the victimizer rather than tolerate the social ostracism. Again, it is widely acknowledged that the relatives some of those abducted even refused to take them again. The discourse of history by no account comes nearer to recounting the lived experiences and realties of the time and event.

The combined strength of the discourse of nationalism, communalism, and patriarchy try all their best to select facts and create fictions and suppress the tales of bitter struggle by minorities and females to live on. But life in these discourses has no meaning compared to the need of the nation, community and religion. Tales of valour, duty, courage, and sanctity simply obscure the tales of mutilation, brutal rapes, and terrible murders. But memories cannot be so easily erased simply by not taking or writing about the events. The effect of violence, rape, and murder is a continuous presence in the communities of the subcontinent and no matter what the history teaches, communities are constructing and reconstructing their lives and societies through these contradictory and difficult memories.

The above story significantly highlights the indifference of a state towards the terrible suffering of its people. Though indispensable, the ruling elites tend to view the general population and moreover the women, dalits, and lower class people as primitive, uncultured whose behaviors regarding the violence need not be a subject of rational analysis; was outside the domain of history proper and ought to be relegated to aberrance, a minor disturbance in the project of ultimate perfection. The so-called lack of rationality behind the violence in the wake of partition authorizes historians to ignore its specificity or comment it on the passing since its sheer scale does not allow a complete exclusion. Regarding violence, the general population is best kept at darkness lest their primitive instincts again come to the forefront thereby undermining the historical mission of the nation. Hence for the innocent masses of people who have no will of their own and are prone to lose sanity 
even at a slightest provocation, the historian as an agent of state is always there to sort out the benign facts of history. Statist historian describe partition in careful constitution detail and seek to explain in terms of political arrangements which when checked against local narrative and memories come across very differently and sometimes opposingly. Violence, rape or murder hence were the natural and even inevitable or unavoidable outcome with the people largely ignorant, fundamentally religious, and sectarian with a history purposefully moving toward the ultimate perfection and happiness of humanity as a whole. Those ignorant class or classes of people needed careful guidance and education from the ruling elite just as the later needed it from their colonial masters. So the history of violence not surprisingly reproduces the same colonialist gesture toward the people of the subcontinent.

But violence has never had the same fate. Whereas it is easily relegated to obscurity when it comes to Partition, it is at the helm of nationalistic propaganda when it comes to the violence perpetrated or suffered by the country during the wars and skirmishes. A nationalist intolerance is daily reinforced by school textbooks, patriotic songs, movies, media stories, and box office hits and no longer noticed vocabulary of everyday national politics. The never-ending tales of past military and political glories are recorded or faked into the history books and national memory is designed to prepare the people for further glories if need and conditions be right. May it be the three wars between India and Pakistan, the World War II, or the genocidal violence, the same underlying logic of a nation or people's glory and its demand for rightful place in history invariably come into play. The obvious sanction of state violence, along with the glorification of chauvinist values as courage, duty and dignity directly incites sectarian and religious violence. But still, the nationalists largely refrain from accepting the stain of sectarianism accompanying those wars. Geopolitical interests notwithstanding, the wars were instigated partly by the deep-rooted prejudices between the two countries. Hence, all the wars or violence between the two countries and internal strife should be seen in a continuum of violence. Religion, as Pandey suggests, "is consigned to oblivion in the best" (54). But despite all attempts, religion remains, however disturbingly, a subject of contestation between and within two countries and the communities.

Partition historiography hence has been largely nationalistic and patriarchal in nature. It has tendency to endorse any and every act of violence regarding national interests and ignore other as natural unease felt by millions at the dawn of Independence. This double standard regarding violence has apparently been learned by historians from the master Hegel who regards only the violence perpetrated by a nation as worthy of getting entry into the discourse of history. So any attempt at critiquing the nationalist historiography should take into account the duality of violence and examine the little histories since neither states and large organization, nor original causes exhaust the domain of histories. Little histories marked by social practices, memories, and rituals may lag behind under the strain of traditional historiography but since they are deeply rooted although unpronounced remain as potent as ever. Attempts at normalizing and homogenizing fell apart only when those little histories are brought to bear upon the social and political reality of the present.

In a nutshell, to what extent partition as a constitutional and political arrangement changed the life of Indian and Pakistani can be a subject of debate and discussion. But what it indeed did and did very successfully was to embitter the two communities by keeping them firmly set at each other's throat. Also paid was the price far exceeding the price for freedom. It is therefore necessary to acknowledge and document the deaths, trauma, and suffering of the millions in the course of independence and partition as a token of justice to the victims that can also serve as a dire precedent for any future catastrophes. Thus, the enormity and ruptured complexities of Indian historiography can only be unearthed through a systematic questioning of all the homogenizing tendencies ever present in Indian historiography. The history is inherited from the liberal humanism and the civilizing mission of the west that has caused the deliberate and systematic marginalization of the minority group like Muslim. 


\section{METHODOLOGY}

The qualitative research method has been adopted in this paper. It tries to review and analyze thoroughly the nature of violence represented in About Daddy (2000 AD) by MeeenaAroraNayak and Looking Through Glass (1995 AD) by MukulKesavan in footings of Priya Kumar's book Limiting Secularism and the locus of the study is based primarily on the critique of partition historiography posited by GynendraPandey. Based on the secondary source of print materials, it tries to explicate what the postcolonial critique of partition historiography reveals the absence of the trauma of the violence and the subaltern perspective of the events. In the analysis of the partition violence, the question of religious coexistence in post partition India and its relation to the concept of secularism is significant. Thus the position occupied by Muslim is addressed in the present study. The identity of the Indian Muslim is constructed as intimate enemy or the stranger. A Muslim is not quite a friend. To deconstruct the very concept, it requires dealing with Indian partition history in relation to religion, nationalism, violence and the politics of secularism.

\section{Analysis and Discussion: About Daddy and looking Through Glass}

About Daddy and Looking Through Glass reveal the absence of trauma of violence and subaltern perspective of the events. The novels written at a time when Hindutva was very high in India, present a secular view of history to reject the Hindutva view of Indian history of the partition of India which looks upon the Muslim as the villain and enemy of the country. The neutral and objective representation of violence is the locus of the analysis which assesses critically the Muslims are the aliens and fundamentally opposed to the creation of a unified India or Great India is derived directly from the ideology of Hindutva. Avowedly hostile to the creation of Pakistan and generally toward the Muslims political and cultural aspirations, the novels highlight the Hindu nationalists' dream of reuniting Pakistan into greater India. The novels draw the references of partition and the dominant scenarios behind it. The characters in the fictional mode represent the different sides of the Hindu and the Muslim communities. The contemporary politico-religious movements are heavily emphasized in the novels. The novels also deal whether the principle of secularism carried by Congress can give justice to the citizens of India or not, no matter Hindu and Muslim. The critique thus focuses the limits of secularism alongside the representation of violence and trauma.

It was the 1990's decade in which BharatiyaJanata Party (BJP) became dominant in the Indian political scene that critiqued the limitations of secularism prophesied by the Congress party in India. The criticism highlights that the principles of secularism has followed the model of Enlightenment project. This western model presumes self and other. How can a political party based on the principles of Hindutva or Hinduness provide justice to the Muslims? Isn't the justice right of the Muslims as it is of Hindus in India? Or should they be driven to Pakistan? Should Muslims prove their nationality when they want to continue living in India? Why does nation constantly accuses that Muslims' loyalty remains in Pakistan because of their affinity to their holy land? Thus, the principle of Congress cannot justify the Muslim citizens in India.

About Daddy begins with the reference of partition. Narrator recalls that her father had once said “Don't cremate in India...sprinkle my ashes in the boarder so that I can feel the wound..." (About Daddy 1). The reference highlights the motive of Hindu nationalist who dream of uniting Pakistan to Greater India. She remembers her father regretting about his deed in relation to Indian partition: "I killed the trust between Hindu and Muslim" (2). Generally, Indian nationalist history accuses Muslim as perpetrator of violence but Nayak scoops the reference of narrator's father as Hindu perpetrator lamenting his deed in the old age, death bed. Simron, the narrator in About Daddy defies the police when she was arrested. Indian elite superiority can be sensed in her words: "I am an American citizen. You can't do this to me. I have half a mind to inform my Consulate about this" (8). Later when she was sent to jail she seeks freedom which she symbolizes as "I climb onto it and look out. In the distance, I can see the border lit up with numerous lights like the site of a carnival-a desolate, ghostly carnival 
devoid of people" (10). The narrator indulges to many activities to be released from the jail cell and meets the people/victims with the history of Indian partition. And she brings the events of partition history of India till her return to the US.

Similarly, Kesavan's unnamed narrator in Looking Through Glass falls in the river during his journey while he was taking the ashes to Banaras because his Dadi had written her will that she wanted it tipped in the Ganga of Kashi.I was taking the ashes to Banaras because Dadi had written it in her will that she wanted them tipped into the Ganga at Kashi. Everyone in the family thought they understood why but they didn't. Dadi's wish had nothing to do with the holiness of Banaras; it was her salaam in death to the martyrs of 1942, many of whom had come from Banaras and its neighborhood, her last attempt to be part of Quit India rebellion. (Looking Through Glass 7)

Kesavan's narrator, now falls in the frame of a Musim family, transcends to the past. In the novel past refers to 1947 and plunges to highlight the consequences of partition violence. Through this image of the narrator falling into what may be called a frozen moment (the time of partition), the novel asks us to question the boundaries that demarcate the past from the present. 1940s was present, on the one hand, the British war-time attempt to foreclose any possibility of another successful mass-civil disobedience movement such as that of the 1932 Salt Satyagraha, on the other hand, there was the Congress demand for an immediate mass action for independence. To that end Congress wanted the Hindu-Muslim unity question to be held off. Gandhi's new mantra for an urgent and radical civil disobedience movement in 1942 posited a program of "Do or Die." The claim is that if Gandhi had not suddenly changed his mind about Quit India, then partition could have been differed. This decision put a brake on Gandhi's earlier promise to put the issue emphasizes the significance of this breach of promise for Masroor and those like him. In this sense, the timing of the Quit India gives a further twist to the pressure of communal claims from the Muslim League and the Hindu Mahasava. Masroor was against Quit India because “There was a war on. And there were Muslims who didn't trust the Congress. Only six months ago Gandhi himself had said that he wouldn't start a civil disobedience movement without a settlement to the Hindu-Muslim question. But now, said Masroor, agitatedly pouring himself another cup, he's asking us to do or die! (38)

The most importantly, it makes invisible the space of agency occupied by the Indian Muslim because within this register, the Indian Muslim is cast either in the role of the 'Congress Lap Dog' or the Muslim separatist. The question of invisibility first enters the novel through the absence or invisibility of Dadi (the narrator's grandmother) as a nationalist figure. It is this absence that forms the text of the narrator's presence in August of 1942. It provides a useful framework in which to think about issues relating to visibility and the politics of representation, for Dadi, as a social worker, was at the time of the Quit India movement involved in reform programs such as the establishment of a shelter for fallen women and the implementation of Gandhi's economic program of Khadi and Swadeshi. She was unable to participate visibly in the Quit India movement. Given nationalism's emphasis on direct political participation, social activism such as Dadi, was perceived as being situated at the outer boundaries of real nationalist activity.

Dadi internalizes the guilt about her non-participation in the Quit India Movement and finds that she cannot rid herself of the memory of 1942. When the government of India awards her a Freedom Fighter citation for her contribution to the Indian independence struggle, her suffering becomes even more acute. Even though Dadi was jailed in the 1932 nationalist movement, she is so burdened with a sense of guilt about not participating in the real struggle for independence-the Quit India movement of 1942-that the pension award for doing so makes her virtually disappear. She insists on returning the Freedom Fighter's award, as she states: "I have the three thousand six hundred rupees they've given me so far, she said. I haven't spent any of it. You must take it to the accountant in that office and give it back to him...make sure he crosses my name of the ledger" (Looking Through Glass 4).In Masroor's case, a mere glance at the headlines of the August 9 Newspaper is enough to bring this about. The narrator cannot tell what has become of Masroor. The very act of narrating Masroor's

American Research Journal of English and Literature

Page 9 
disappearance to a bewildered Ammi and Ashrafi highlight the death, horror and terror of the time of partition. The narrator as amnesiac is forced to confront the unsettling experiences of 1947 with the uncertainty of the participant. In About Daddy, narrator asked his father whether Muslim hurt him then he replies as:

Yes. They killed my father, too. I could see his Adam's apple bob as he swallowed hard. But that didn't happen in Lahore. You see, in Lahore, people lived together in peace, they didn't want to be divided. But they were afraid. They will soon enter Lahore, too, so the young men in Lahore began to watch out for strangers in their streets. They began to watch out for strangers in their streets. They began to patrol their neighborhoods with whatever weapons they could find: kitchen knives, axes, staffs, anything. (About Daddy 14)

Kesavan's narrator is literally taken to the pre partition past(1942), one of the most politically charged years in the history of Indian nationalism. The narrator protagonist then no sooner encounter with Muslim family, starts examining past critically. As the story unfolds, he takes the shift as secular Hindu protagonist who becomes alien in the Muslim family. He becomes aware that the partition was an earth-shattering event. The question of distincition between the religious and secular remains traubled in the texts. Priya Kumar quotes Shefali Jha's work on the question of religious freedom:

(I)a "no concern" position of separation of state and religion that comes very close to the hegemonic western understanding of the privatization of religion; (2) the flip side of the first position, which demands separation but does so out of a concern with protecting religion rather than with emancipating the state; (3) the "equalrepect" theory, which affirms that the state should respect all religion equally rather staying away from them altogether. (Limiting Secularism 17)

But the narrator in Looking Through Glass lives in the constant fear that the Muslim family of Ammi, Masroor and Asharfi will either die or make their way to the newly constituted Islamic infant nation named Pakistan. This upper caste Hindu narrator acknowledges a very different understanding of partition. The novel revolves around this unfamiliar representative subject of postindependence India. Then, it reveals the majoritarian presupposition of secular Indian citizen.The novel highlights that a normative upper caste Hindu self that seeks to represent itself as culturally neutral, i.e. secular. Moreover, narrator's and Hasan's childhood perceptions mirror the cultural differnces between Hindu and Muslim. Masroor's family as an upper caste Brahmin believes that a mosque is a muslim hatchery. The Muslim in the narration is described as 'other'when Masroor sharesalthough his father's Muslim friend, Mirza, is allowed to visit them at home and is even served coffee, the glass he uses must be cleaned with burning coals before it can be used again. Muslim is considered to be 'dalit'. The narrator realizes how he was raised on about the stories of Muslim excess.

Looking Through Glass interrogates the essential and fixed differnces between Hindus and Muslim, and offers the critique of the homogenizing discourse of Indian secular nationalism. The Congress party claims itself secular and thus 'neutral' but ties of religion, cultural, language and caste. Though it chants 'we are Indian first', its ideology is shaped by the majoritorian upper class Hindu. Moreover, it takes it ideological base from the Enlightenment project of the west. Muslim in India are required to authenticate their nationalism whereas Hindus are never asked. Thus, the novel highlights the limits of secular nationalism as well. The limits of the secularism carried by the Congress party is further emphasized by the spokesman of the Muslim viewpoint, Masroor, in the novel. He narrates that eighty miliions Musalmans in this country are invisible. Musalmaans are not invisible to British, even not to the Hindus who hate but to the Congress party which is blind. The right wing Hindus hate Muslims and Nehruvian Congress constructs invisibility to them, i.e. it claims to represent all Indians. Thus, the choice for the modern nationalism is either to assimilate into the dominant nationalist culture of majoritarian or to be stereotyped as disloyal. Masroor is disillusioned at the treatment that the Congress party has done with its Muslim members. Congress Muslims disappear after it proclaims its resolution that the British must quit India.

American Research Journal of English and Literature

Page 10 
A historical watershed about Looking Through Glass is the Quit India movement of 1942 which intensifies the political rifts between Hindus nad Muslims. Masroor doesnot oppose the political agenda of the Quit India but just disagrees about the timing of the declaration. Those Muslims who disappeared from the common resistance were accused of demanding seperate Muslim state, however, they were committed to 'undivided India'. It is the Congress's refusal to understand the Muslims. Such protagonists encounter with the Muslim other succeeds Kesavan's interrogation of official secular nationalism. The novel interrogates the enlightenment narrative of the oneness. The religious that have been called 'other' can never quite be the same as majoritarian one. And the privilaged majoritarian always secure their authority. Thus, Kesavan problematizes the rifts between Hindus and Muslims. Hinduism is considered inherently secular and the Muslims are rendered as rigid and fundamentalist, and therefore inferior to majority Hindus in the concept of Nehrivian secular nationalism.

The Congress League politics in the era of 1940s is blamed to drive a demand of a separate Islamic nation due to the unyielding stance on various issues (untimely demand of Quit India, deadlocked Simla Conference of 1945...). Masroor's mother, Ammi, in the novel represents the dilema just before the partition. She supports neither Nehru's Congress not Jinnah's League, she is considered to preserve the present undivided India she inhabits. Finally, she contests the election as an Independant candidate from Lucknow and lanunches a party. Her unusual election manifesto that outlines what should be done after British departs from India. When a journalist asks her about the launching of the new party, she desires to live in the place, where she has spent long years waiting for her missing husband, Intezar. Thus, through the narration of Ammi, Kesavan reminds us the possibilities of Congres's secular nationalism and the critique of Muslim League as seperatist. Kesavan's Hindu narrator witnesses a number of Muslim families being displaced by partition. The displaced narrator finally assumes that his adopted Muslim family would have been better of in Pakistan. Such retrospective narratives allows Kesavan to create Muslim identity in the 1990s of India. It was the decade the ideology of Hindutwa was in very high and cosidered Muslim as seperatist of India and villian of the country. Finally, the narrator does not find his way back to his own time represents the long term effects of partition violence that millions of people have been adversely affected and trapped in the quicksand of repeated violence..

In About Daddy, the narrator penetrates to the reference of violence when she converses to the people in jail: "Farzana, a new girl from Pakistan in the jail cell called the narrator enemy with the contempt of a racial slur Indians are our enemies. She was from Pakistan. Her parents had recently migrated to the United States. I'm not Indian, I'm American, I told her" (About Daddy 10).Then, narrator seeks her identity and monologues: I hate rain. I sat up sobbing. I hate it. It's hurting all those people in the new country India made. I hate it. I hate you. I want to be Indian. Why don't you ever tell me I'm Indian? You're Indian, Daddy's Indian, and then how come I'm not? ... I hate it. I'm nothing. I'm not American, I'm not Hispanic, I'm not from Pakistan, and I'm not Indian, What am I? ( About Daddy 12)

She had also argued to her parents regarding her identity and the mother consoled her that she is an Indian and blames to her parents why they are not having conversation about Indian partition: "If I am, then how come you never talk to me about India, how come we never go there to visit, how come we don't speak the language or wear the clothes or talk about it? How come you never talk to me about India? Did you know that there was war in India?" (12). After a long silence father replies that he was the cause "because I love India here, he touched two fingers to his heart. But I hurt her. I hurt India. I hurt her very badly" (13). Father takes the blame of partition, he laments for the undivided India and recalls Gandhi, who could not stop the partition though he was able to liberate from British Raj:because some Hindus and Muslims who didn't want to live together any more stared killing each other, and the British, who ruled India at that time, divided her into two parts. They gave one part to the Muslims and the other part to the rest of the people. So the people who lived on the wrong side had to leave their homes and go to the side they belonged to. But there were some bad people who couldn't wait for them to leave. They began killing them all. (13)

American Research Journal of English and Literature

Page 11 
Father continues with repressed memory of the 1947 when he involved in riots. He confesses, "I killed people who loved me. I killed the trust between Hindus and Muslims so that they would never be able to live together in peace again. I helped divide them forever. I helped divide India. I tore her apart. And I left her bleeding and ran away and I can never go back" (15). It shows that not only the victim but also the perpetrator gets traumatized. The text draws the war reference. Killing, rape, riots and hacking were common phenomena. As Simron asked Farzana about her grandmother's arm and she replied "someone cut it off a long time ago during the Partition riots back home...All I could remember was seeing Daddy standing in a street hacking at people with his sword over and over again, slicing off heads and arms" (35).

It was during the partition the violence in women was frequent. When narrator was transferred to Amritgarh jail she witnessed the violence in women "There is no one. Her family has disowned her. A women's honour is everything. Her family will never forgive her for losing that" (About Daddy 57). The prestige of women remains in her sanctity regarding sex and rape. Narrator becomes aware about two fractions as Hindu and Muslim. This unrevealing of the discourse of trauma in Indian English partition fiction shows a shared interest in the relationship between 'trauma' and the politics of historiographical representation. Narrations of the texts in analysis expose the Hindu Muslim relation before and after partition:Matinee says she's a terrorist. That's why she's kept locked up. She is dangerous. ..For religion, they say when they are among people, and when they are alone, they fuck that same religion. They rape, they loot and live like kings. What religion? There is no religion. It's all politics and personal profit. They're all alike, these Hindus, Musalmaans, terrorists, all of them. chutiyasaale. It's only because of them that one community has become thirsty for the other's blood. (58)

The attempt has been to study the cultural shaping of memory, to examine the roles of cultural usages of memory and narrative and to look at the social context of production and reproduction of Indian partition texts. Though Gandhi and Nehru are thought to be similar in the issue of secularism; they are different in terms of religion. Priya Kumar in his book Limiting Secularism quotes Gandhian view of religion in relation to politics: While Nehru was a confirmed agnostic, Gandhi's life was permeated with his commitment to religion. In a famous early statement, Gandhi wrote: "Those who say that religion has nothing to do with politics do not know what religion means. Elsewhere, he affirms; politics divorced of religion has absolutely no meaning." Accordingly, he advocated the notion of sarva dharma sambhava rather than endorsing the exclusion of religion from public life. (21)

Yes, secularism and religion are interpreted in the favour of the hidden political motive. Similarly, when memories are produced and reproduced, different interest groups can manipulate them. Muslims and Hindus can define the same event from two different perspectives rather than the victim's perspective in relation to the state. Simron converses with Sultana:Koki told me you are a terrorist. 'Perhaps,' she says. They killed my father, my neighbours. They ruined my brother's life...I killed two men, she finally says... why did they burn your house?' Because we are Musalman. My father told me about the partition of India and Pakistan and about the enmity between the two communities, but I thought, I hoped, that had ended with the partition. (About Daddy 101)

The formations of Indian and Pakistani identities depend largely on the mediation of partition violence of 1947. "Gajji was a Hindu, and people were afraid the League would hurt their sons in his akhara. Amjad's parents were afraid too and they withdrew daddy and Amjad" (105). Communal sense ingrained in Hindu "They killed my father, GajjiPahalwan. They call us kafirs. If they think we are such a threat to their Islam" (109). Sultana adds to the stereotyped image of Muslim by the Hindus: "Every time there was tension between the two communities in any part of the country, the Hindus in KarimGali made us suffer. The shopkeepers were rude to us. The boys called us names. They started fights with us on the streets and threatened us. It was hard to live" (102). Such occurrences were common during the partition violence. It is also the representation of violence-the pains and cultural traumas, the abduction, migration, genocidal murders and the tales of rape-that constitutes partition. Dominique Lapierre and Larry Collins outline intensity of the gruesome violence in graphic detail:And so, in a bewildering frenzy, Hindus, Sikhs, and Moslems turned on each other. India was ever a land of extravagant 
dimensions, and the horror of the Punjab's killings, the abundance of human anguish and suffering they would produce, did not fail that ancient tradition. Europe's people had slaughtered each other with bombs, shells and the calculated horrors of the gas chambers; the people of the Punjab set out to destroy themselves with bamboo staves, hockey-sticks, ice-picks, knives, clubs, swords, hammers, bricks and clawing fingers. There was a spontaneous, irrational slaughter. (Freedom at Midnight 359)

Death and destruction was unremitting and did not spare anyone. All three communities paid heavily and dearly in that terrible upheaval that would leave an indelible scar upon millions of people of the subcontinent. Beginning with the late twentieth century, the world has witnessed a continual rise in religious sentiments around the world as part of identity politics. With the fall of Soviet Union, according to Samuel P. Huntington, "The most important distinctions among peoples are not ideological, political or economical, they are cultural. And the most dangerous conflicts are those along the fault lines between civilizations" (The Clash of Civilization 21-28). The Indian subcontinent as a centre of two major civilizations hence provides a space to look into the nature of the undergoing clash between two civilizations. In fact, the clash envisioned by Huntington took place some sixty five years ago from today when a separate land was created given the logic of the inability of two religions to live together in India.

Muslims in the society are considered the aliens and fundamentally opposed to the creation of a unified India or Great Indian. The novel emphasizes the religious and even inter-national co-existence. Hindus consider Muslims as other and blamed them as violent and disloyal to the country in terms of nationalism. The government formed by majority of Hindu considers Muslims as treacherous. The Hindutva ideology of Indian political party considers Muslim as the cause of partition mistakenly. As Sulatana speaks to Simron: "We are Musalmaan, behen. This is not our country. The police are not concerned about what Ifti's Abu, Ghulambhai's wife and unborn child, Khala's son and daughter-in -law, my husband...We don't count as citizens, except, of course, when it is time to ask for votes" (About Daddy 159).About the 'post-war excesses, Nayak writes from Simron's perspective "I certainly feel like a war-weary veteran, except, I'm not sure I want the memory of this particular war to be erased so easily" (123). Simron had only heard about the consequences of riots and communal violence but as she visited to KarimGalli and met Sulatan's brother she shares to Scott, her boyfriend: "words have died in my throat like aborted embryos. If I open my mouth to speak now, I will only spew their blood" (164). Then, Simron uses the simile about India as "It looks like a glittering island of blood" (167). The partition affected millions of people. The victims of the event cannot be justified with pension or any sort of compensation.

A number of peace and harmony prophesied organizations themselves were found inflicting violence, indulge in rape, loot and biased towards the minority group like Muslim. It is evident in Nepal also that after a decade of Maoist insurgency, thousands of victims are left bereaved, destitute, disable, hopeless and lame. The committees formed to compensate them can not justify their suffering. In the name of smooth functioning of the nation, for the time being, for full and emancipatory democracy, for the liberation of the people are the popular clichés to console them, which do not fully justify the victims. It is its repercussions that small groups of violence have been emerged in a multiple number with deliberate hidden politics of economy, culture and misused or blackmailed by external forces. Only a handful of people take part in the central politics and rest of the great mass behind is not addressed adequately. The claim is that even a greater number of people with horrible tales can never be fully justified. After the India partition, organizations were supposed to be opened to minimize the pain to avoid volatile riots. One of such reference is found in the text to critique: "He's head of the CCPH-Citizens for Communal Peace and Harmony. It's a very well - known organization, in umbrella organization for other, smaller units. And Kalida-he's one of the most respected men in Amritgarh. You're safe from the police here. No one will look for an illegal alien in Kalida's house” (191).“I am composing an agenda for a peace rally; we are having on $6^{\text {th }}$ December to observe the fifth anniversary of the demolition of the Babri Masjid" (196). On the one side Simron evaluates the relevance of communal peace and harmony organization and on the other hand in retrospective recalls her father whom she had promised to sprinkle his ashes "I just want you to promise me 
something. Promise me, that after I die, you will take my ashes to India and scatter them on the border of India and Pakistan" (196). Her father had guilt that he caused the partition of India and Pakistan. She associates him: "he felt he caused the division. He hurt a lot of people, and then he ran away. He never stopped feeling guilty about that. All his life he felt guilty, and the worst part was, he couldn't come back. The pain was so vivid" (211). The narration reveals the perpetrator regretting for his deed after the partition. It highlights that the Hindus and Muslims are equally responsible for the partition. Then, Simronawares Scott about the event which her father had committed about a half century earlier as "we absolve him of all his sins when he departs. That is why all ashes are scattered in the Ganga. We believe her waters liberate a person from all guilt. Don't you think your father deserves that?" (211). The reference supports the principle of living together rather than creating a hostile relation between Hindus and Muslims.

Will the present communal violence lead eventually to peace? Simron questions to herself. She recalls the people speaking in jail "there was someone. A haramzada police wallah-used to think every Sikh is a terrorist. Finished off every single Sikh male in the village" (223). And then, suspects Kalida for perpetrating violence: "The news of the bombing of the school bus in Karachi precedes Kalida's arrival" (231). She monologues "Behind the disguise of religion, treachery smiles" (251). Is Kalida a Gandhi figure in the text? Then why does Gandhi figure perpetrate violence? People ask him to stop Shivaratrijuloos in Muslim market. He gives speech for brotherhood. But as Simron becomes suspicious about the activities of Kalida and tells "Daddy's soul will probably never find peace, that there seems to be no redemption for him" (243). Shurajit informsSimron about $\mathrm{CCPH}$ and its works:Oh good things happen, too. Sometimes we are able to talk to people and curb potential violence. We try to diffuse volatile situations. We mediate between the people and rash government measures. We organize protests. Sometimes we are effective. That's why I've stayed here so long. Kalida has taught me a lot. He's made me care. (199)

But, the narrator declares Kalida a social activist with Arun: "I also know Kalida went to Kashmir, not to talk about peace to the militant groups there, but to deliver these letters and God knows what else, to his accomplices so they could be taken Sind. "Answer me, Arun. The communal riot after the Babri Masjid incident, Janki Das, Sultana's house...was CCPH party to that in some way?"(283). Yes, the highlights of such committees working in peace enhance the co-existence in between Hindus and Muslims in India.When Arun takes Simron, the narrator, toKalinathBandopadhya (Kalida), a piece activist of Citizens for Communal Peace and Harmony (CCPH), first, she questions herself that what will such organization do when violence already took place. But as she learnt they could avoid a lot of volatile situations and then she decided to stay. She suspected Kalida himself being involved in terrorism when the news of bombing of school bus in Karachi preceded Kalida's arrival and found a pamphlet about the 'Appeal for Violence' printed in CCPH's office. She knew that Kalida was helping the cause of violence. And then called Arun, met him but left him as he took Kalida very normally. Hindu -Muslim riots take place as the procession in Shivaratri is taken through Masjid. When Kalida sleeps on the road to block the mass to avoid the communal riots, the crowd steps upon him and Kalida is dead. When Simron witnessed Kalida trying to stop the riots upto the last moment, she thought more about co-existence between Hindus and Muslims. Then, Simron returns to the US with her boyfriend and watch bombing in Amritgarh recalling Kalida, father and of course thinking about violence and partition. The narration does not stereotype but mirrors the repercussions of violence vividly.

Again, the narrator in About Daddy recalls the time of her father who traumatized and lamented for undivided India:And I weep. I weep for my father. I weep for his life. I weep for the death that evolved from his life. I weep for that violence that tore him from his life. I weep for him. I weep for the guilt he carried through his life unto death. I weep for him, for he was a victim not only of one act of terrorism but of all acts ever perpetrated, for each act multiplied his crime and pronounced him a victim of his own guilt over and over again. And he is dead. My father is dead. Deep sobs roll through my body. (272)

American Research Journal of English and Literature

Page 14 
The guilt of perpetrator is more intense when he recalls more about the milieu of partition. It tells that not only the victim but also the perpetrator suffers in violence.In exposing the tension between embodiment and reflection and its relation to the politics of visibility, the novel chronicles the ways in which Indian nationalism has snapped the Muslim body into the stereotype of a separatist. When Sultana was transferred to maximumsecurity central prison, Simron writes about ethnic cleansing and bloodbaths of partition:I write about Gajji and Sultana's father, individuals who forge paths of communal harmony in this labyrinth of hatred. I write about Daddy and Sultana, youth lost in blind rage and revenge. I write about India, the country my father lamented in his dreams and loved in his deaths. And I write about myself and unwilling participants forced into the midst of it all and now hopelessly involved. That night, lying under the blanket, I see Daddy's horrifying image replaced by Sultana's. (About Daddy 113)

The novel dwells in the precarious, the unintentional and the failed attempts at activism of the ordinary people of Indian nationalist history. By doing so, it attempts to disturb our tendency to automatically link agency with the subject's attention and with the visible realization of the intention. Simron, in About Daddy recalls the confession of her daddy and monologues:Suddenly, I see them as inheritors of Daddy's legacy. These could have been the very same people in Lahore, the people, the people Daddy massacred in his mindless rage. There are so many apologies I want to offer them, so many amends I want to make. How can I leave now? If I let him go, will I get a cab back to the hotel? (160)

Narrator plunges in the quicksand of 1947 Partition violence. The more she knew about war, the greater the penetration she made about repercussions as she replies to Scott what she saw in Sultana's house "I saw what Daddy did, I say almost in a whisper. I saw what he started. You should have seen Ifterhar's burnt arms, Khala's grief. She lost her son and daughter-in -law in the fire. These are the very People Daddy hurt, Scott" (About Daddy 166). The narration also focuses in the passionate and failed attempts of Masroor to stop a communalist cricket match organized by British between Aligarh Muslim University and Banaras Hindu University. The narrations without communal standpoint solicit for living together.

Moreover, the novels describe the events highlighting the human dimension. The narrations interrogate the notion of essential and fixed differences constructed in the nationalist history of India. Narration projects the sudden and unexpected nature of violence:People were out buying supplies for the day. They cowered before him as he jumped off the horse and advanced towards them, a terrible fire burning in his eyes. Severed limbs, decapitated heads fell around him like windfall fruit. Reeling bodies collapsed at his feet. With every blow, blood vessels burst, squirting his face, his hands, his body. (About Daddy 110)

Care is taken to present oneself as a victim rather than a perpetrator. Scott and Simron converse: My father started that Perhaps. But those times were treacherous. Thousands turned murderers overnight. The whole nation turned violent. Your father was no different. But what those misguided people started at that time is not an excuse for what is happening now. Those people are not to be blamed for today's problem. Let me tell you about today's India. It might be a reflection of 1947, but believe me, it is a false reflection. What is happening today has nothing to do with what happened in 1947 . What your father did was over after the Partition. Today, it is all Politics. (212)

The intensity of violence is determined by the need to preserve the dignity amid all around humiliations. It is also a primary means through which communities reconstruct themselves. Reports regarding casualty figures and the condition in the immediate aftermath of violence either faithfully or not so faithfully try to create an atmosphere of impending doom or a great calamity. Clichés like "Hundreds Dead", "City on Fire" etc play upon the imagination of the readers. The urge and calling for revenge were common during the partition: "My Hindu brothers, the time has come for revenge. There is loud applause from the crowd. Show them, my brothers, that Hindus are not eunuchs. A war like yell breaks out as if the revenge would be meted out this instant. People fall upon each other, beating and clawing" (236).

American Research Journal of English and Literature

Page 15 
Here unconfirmed reports and rumors depart from their initial indeterminacy and anonymity to certainty and even excess. The uses of rounded-off figures like hundreds burnt alive are one indication of the persistence of rumour. And there is no legal restraint on multiplying the number either for journalistic or political advantages. The partition discourse relating to 1947 perpetuates the message and method of rumours- a principal factor of the discourse. It applies a journalistic trend to cite the casualty figures although it is concerned with much greater figure. Partition historiography adopts a method of taking median or averaging. The problem in these discourses that give credibility to an average figure lies not with the numbers themselves but with the absolute certainty and objectivity they seek to assert in the guise of objective narrative. GyanendraPandeyargues, "Statistical truth is not the main point at issue. What is at stake is a grim political message, bolstered by an axiomatic history" (Remembering 81). After visiting KarimGaliSimron speaks to herself from the perspective of subaltern as: "Daddy I whisper, I know your guilt now. I know that I cannot leave this country till I have delivered his ashes to the penance he craved. I also know I cannot abandon him to an eternity of that penance. I know I cannot leave now, because I am my father's daughter" (About Daddy 163).

Pandey's critique of nationalism can be brought to bear upon the literatures written on the themes of partition violence. The novels concern in perception of its central protagonists amid the confusion and catastrophe before, during, and after the partition, and engage in what Pandey calls 'rhetoric of blame' and what Jameson calls 'the politics of blame'. Although a continuity of nationalist rhetoric, the novels nevertheless attempt a critique however inadequately of Hindutvaideology and its perspective minority Muslim population in India. The narrations in the novels of analysis also critique the politics of stigmatization where an individual (or community) that might have been received easily in ordinary social intercourse is, as Goffman states, "readily othered and demonized thereby breaking the claim that his other attributes have on us" ("Stigma" 205). In light of the deep bond that emerged between Hindus and Muslims in their common struggle for Independence, the murderous bitterness can be attributed also to the stigmatization of differences. The communities those were mutually acceptable some time ago despite some differences suddenly become completely unacceptable due to the tribal stigma of race, religion and nation. In About Daddy Sultana further adds:All the Gajjis of the world are either dead or being killed. There is no one to stop the violence anymore. My father tried, but they killed him. They couldn't believe he loved this country. All they cared about was that he was a Musalmaan. As if being a Musalmaan excluded him from being Indian or Human. My neighbor, GhulamBhai, his wife was pregnant. She died in that fire. She wasn't a Pakistani spy. (105)

However, the intimate bond among the religious communities is foregrounded simply to highlight the impending fall apart and co-existence of Hindus and Musliims. Acting as a contemporary history written to record and analyze events, novels often function as a strong ideological vehicle for propagation of national propaganda and politics. The texts of analysis thus speak of the marginal area that helps to bring a balance to create a just society where people will not be judged in terms of religion but in terms of his or her potentiality. Indian Congress backed by Hinutva and the majority of Hindu elites or fundamentalists should reconsider their view of Muslim. Kesavan cites the critique of Congress in relation to its politics and nationalism: "If the Congress can humble the imperialist eagle, why can't it deal with the Muslim League crow? The Congress is the party of all sections, of all classes, of all sections of all classes. Those who do not support the Congress will rot in the dustbins of history (applause)" ( Looking Through Glass 234).The novels take great care to isolate national which in turn is nothing more than religious nationalism.

In fact, nationalism in India has long been considered the exclusive domain of Hindu majority; the Muslims being the suspect other. As all nations, nationalisms and national discourses are made in exceptional historical circumstances, Indian nationalism was by every account created in the context of 1947 along with a century of colonial rule and the history of Muslim invasion. So it is by no account unnatural that ethnic and religious identities are the central determinants of privilege in India of today. Although not admitted even by religious fundamentalists, Muslims in India have rarely been thought of as Indians as their primary allegiance is suspected 
to be religiously motivated to Pakistan after partition. So, once the violence takes place what can be the solution to protect it from impending ruin? Can rehabilitation centers or peace and harmony committee minimize the effects of violence? Do such organization really help to ethnorelativism, coexistence and reconsideration of the view of minority. Nayak as cites the limitation of such organizations that "After an incidence of violence, organizations such as ours seem such an apology. Sometimes I wonder if we have any meaning at all....catharsis for everyone but the victims, with our patriotic speeches of nationalism, our rallies... all seems so useless, and every day the violence escalates" (About Daddy 199).

The limitation of such organization is clear. Moreover, they cannot easily change the ideology and stereotypical images of Hindu and Muslim. The majority of Hindu in India suspects Muslim for their loyalty to the country. Moreover, having demanded and got separate land of their own, Muslims have always lived with a taboo of wouldbe-traitors living in India due to technical difficulties rather than with their own choice. The event highlights the predicaments of the Muslims and utter neglect on part of Nehru since the need to prove one's loyalty tacitly assumes disloyalty and that also amidst such violence where belonging to a Muslim community was a recipe for stereotyped images. In the line of similar evidence, Sultana, in About Daddy, emphasizes the changing attitude of people due to war: "I don't think people even know the meaning of that (human brotherhood) now. All they know is anger and hatred. To the Hindus, we Musalmans are all terrorists trained by Pakistan. They hate us and they hate the idea that we are Indians just like them" (About Daddy 103).

The narration spotlights on the meaning of brotherhood amongst Hindus and Muslims. GhulamRasul in his conversation to Simron revisits the trauma of partition in the nationalist tone: "It is like 1947 again. Back then, my parents decided to stay in India after the Partition. They believed this was their land, their soil. I'm glad they're not alive to see this. This country doesn't seem ours any more. It just doesn't seem ours" (105). The narration in the novel assesses the majority of Hindu population psychology. It critiques the position of Muslim subjugated by Hindu majority.However, in another maneuver reminiscent of politics of blame, effort is made to point the finger squarely at the Muslims for stirring up hatred and violence in their campaign. Revenge and threats were frequent during partition: "So, more little girls can die, more mothers can lose their sons, more wives their husbands and more sisters and their brothers? The colour of blood is red. The colour of blood is death. And you saw it today. Blood. Not just Hindu blood, but human blood, a loved one's blood, Indian blood" (About Daddy 237). The narration in the quote does not focus in religion but in general emphasizes the way of living together. The commonalities between Muslims and Hindus are highlighted rather than communal feelings. It critiques that for the Muslims violence is a choice of preference whereas for the Hindus it is a compulsion so as to secure its larger interests. One is overtly aggressive, the other merely defensive. The reference focuses in general like: 'little girls', "more mothers", sons, wives, sisters, human blood...neutralize and emphasize on living together of Muslim and Hindus.

The narrations in the novels help to critique the view of Hindu majority over Musliims. The apparent criticism of Gandhi directly emanates from what has now been labeled as Hindutva ideology that wants a strong army and a militant population ready to fight. Narration also squarely aims at outlining the moral corruption of Muslims, their sensuality, and utter disrespect of women that overtly manifested itself during the wholesale rape of Hindu women. The idea of considerate and kind Hindu man is set against the background of inherently barbarous and lecherous Muslim men. The attempts at cultural smearing become a significant site for the analysis of disparity of political, economical and social powers between the two communities as well. As the events move on and partition becomes a reality, the naked dance of violence comes into play. These events to say at least are yet another episode of blaming and harping on the innocence of one or the other community. However, rather than accusing divisive legacy, partition may be seen as Priya Kumar contends, "I view partition as a spectral presence that continues to inform and haunt both Hindu-Muslim...contemporary international relations in the subcontinent" (Limiting Secularism 85).

American Research Journal of English and Literature

Page 17 


\section{CONCLUSION: EMPHASIS ON LIVING TOGETHER}

In short, the representation of Indian partition violence for/from both Muslim and Hindu is balanced in the texts. The narrators emphasize the violent events without being communal. The narration takes the side of oppressed, dominated and victims' point of view. Both the writers make partition as their theme and are able to reject the unjust ideology of Hindutva. Indian Congress's ideology of secularism has been much critiqued in the texts. And they succeed to recreate the horror, terror and trauma of the partition of India to a great extent.The findings show the effects of a mental map that emerged as a result of partition. First, Nehruvian secularism should start fundamental reconsideration of what Indian Muslim has meant for the secular critical temperament in India. It should not compel Muslim as either to merge into the nationalist mainstream or to be construed as communalist. A state should be able to honor all faith equally rather than prioritizing a majority groups with a vested interest. The events written as mediated should be corrected. The texts must explore the relation of traumatized, absence of trauma of violence, subaltern perspective of the events and the state rather than capturing the human dimensions and covertly perpetuating the clash of different identity markers. Mostly, Indian elites, novelists or writers of history should consider that when memories are produced and reproduced they are also prone to be used and manipulated by various interest groups. Thus, Indian English partition literature should be rewritten from the thin relation to stranger and remote. National, religious and racial trauma or stereotyping should be healed or cured to avoid the continuous fractioning of the communities through the politics of historiographical representation. And the majority groups, no matters Hundus or Muslims, should stop stereotyping each other.Finally, About Daddy and Looking Through Glass offer the ways of living together. The narrations highlight the possibilities of multi-religious coexistence that go even beyond the secular citizenship prophesied by Indian national congress. The nations compel readers to contemplate the limited and constructed position occupied by Muslims in post partition India. Thus, Kesavan and Nayak reveal the absence of trauma of the Indian partition violence and the subaltern perspective of the events in a secular mode rather than communal perspective. And the narrators succeed to establish an offer of animate 'co-existence' as postcolonial project.

\section{REFERENCES}

1. Alam, Javed, and Suresh Sharma."Remembering Partition.” Seminar 461 (1998): 98 -103.

2. Alter,Stephen. "Madness and Partition: TheShortStories of SaadatHansanManto." Alif:Journal ofComparative Poetics 14 (1994): 91-100.

3. Caruth, Cathy. "Introduction." Trauma: Exploration in Memory. Baltimore: John Hopkins UP, 1995: 3-12.

4. Elst, Koenraad. Gandhi and Godse: A Review and a Critique. New Delhi: Voice of India,2001.

5. Erikson, Erik. Gandhi's Truth: On the Origins of Militant Nonviolence. New York: Norton, 1969.

6. French, Patrick. Liberty or Death: India's Journey to Independence and Division. London: Harper Collins, 1997.

7. Goffman, Erving. "Selections from Stigma." The Disability Studies Reader. Ed. Lennard J. Davis. New York: Routledge, 1997. 203-215.

8. Hasan, Mumtaz. "The Background of the Partition of Indo-Pakistan Sub-Continent." The Partition of India: Policies and Perspectives 1935-1947. Eds. C.H. Philips \& M.D. Wainwright. Cambridge, Mass: The M.I.T. Press,1970. 319-330.

9. Hasan, Mushirul. "Partition: The Human Cost." History Today 47.9 (September 1997): 47-53.

10. Huntington, Samuel P. The Clash of Civilizations and the Remaking of the World Order. New Delhi: Penguin, 1996. 
Communicating Secular Representation of Partition Violence in About Daddy and Looking Through Glass

11. Jassal, SmitaTewari, and Eyal Ben-Ari. "The Partition Motif." The partition Motif in Contemporary Conflicts. New Delhi: Sage India. 2007.

12. Kesavan, Mukul. Looking Through Glass. Ed. Farrar, Straus and Giroux. New York: Orient Longman. 1995.

13. Kumar, Priya. Limiting Secularism: The Ethics of Coexistence in Indian Literature and Films. Minneapolis: University of Minnesota Press. 2008.

14. Lapierre, Dominique, and Larry Collins. Freedom at Midnight. New Delhi: Vikas Publishing House, 1997.

15. Manto, SaadatHasan. For Freedom's Sake: Selected Stories and Sketches, SaadatHasan Manto.Ed. Muhammad Asaduddin.Trans. Muhammad Asaduddin. Karachi: OUP, 2001. 112-148.

16. "The Dog of Titwal." The Story and its Writer: An Introduction to Short Fiction. Ed.Ann Charters. Boston: Bedford, 1995. 883-886.

17. Nayak, MeenaArora. About Daddy. New York: Penguins Books, 2005.

18. Pandey, Gyanendra. Remembering Partition: Violence, Nationalism and History in India. Cambridge: Cambridge UP, 2001.

19. “Can a Muslim Be an Indian?" Comparative Studies in Society and History. 41.4 (October 1999): 608-629.

20. "The Prose of Otherness." Subaltern Studies VIII: Essays in Honour of Ranjit Guha. Ed. David Arnold and David Hardiman. New Delhi: OUP, 1994. 188-221.

21. "Voices from the Edge: The Struggle to Write Subaltern Histories." Ethnos 60.3-4 (1995): 223-242.

22. Savarkar, VinayakDamodar. Six Glorious Epochs of Indian History. Tr. \& Ed. S.T. Godbole. Bombay: BalSavarkar, 1971.

23. Talbot, Ian. "Literature and the Human Drama of the 1947 Partition." Region and Partition:Bengal, Punjab and the Partition of the Subcontinent. Ed. Ian Talbot and Gurharpal Singh. Karachi: Oxford UP, 1999. 228-268.

24. Trehan, Jyoti. Veer Savarkar: Thought and Action of VinayakDamodarSavarkar. New Delhi: Deep \& Deep Publications, 1991.

Citation: Udaya Raj Paudel, "Communicating Secular Representation of Partition Violence in About Daddy and Looking Through Glass" American Research Journal of English and Literature, vol 4, no. 1, 2018, pp. 1-19.

Copyright (c) 2018 Udaya Raj Paudel, This is an open access article distributed under the Creative Commons Attribution License, which permits unrestricted use, distribution, and reproduction in any medium, provided the original work is properly cited. 